\title{
Koordinasi Antar Bidang dan Kerjasama Badan Kepegawaian Daerah dengan Organisasi Perangkat Daerah Lainnya di Lingkungan Pemerintah Kabupaten Probolinggo dalam Pemutakhiran Data Sistem Informasi Administrasi Pegawai (SIAP Online)
}

\author{
Mirza Surya Adhitama ${ }^{\text {a* }}$ \\ ${ }^{a}$ Dinas Perpustakaan dan Kearsipan Kabupaten Probolinggo, Jawa Timur, Indonesia
}

\section{INFORMASI ARTIKEL}

\section{Article history:}

Dikirim tanggal: 30 Mei 2020

Revisi pertama tanggal: 26 Maret 2021

Diterima tanggal: 30 Maret 2021

Tersedia online tanggal: 14 April 2021

Keywords: cooperation, coordination, information technology, new public management, service

\section{ABSTRACT}

With the presence of Presidential Instruction No. 3/2003 concerning to thr National e-Government Development Policies and Strategies, the President instructed the implementation of E-Government development nationally in accordance with their respective duties, functions and authorities. The concrete step in the implementation of e-government in Probolinggo Regency, especially the Regional Personnel Agency is the establishment of an Online Employee Administration Information System (SIAP Online). This study aims to describe the Collaboration of Regional Personnel Agencies with other Regional Apparatus Organizations (OPD) as well as Coordination between fields in the Regional Personnel Agency in utilizing SIAP Online. Based on the research that has been done, the results show that the collaboration carried out by the Regional Personnel Agency in the framework of presenting staffing data has gone well. This is due to the support in the form of regional regulations and regent regulations that facilitate the cooperation process with other OPDs.

\section{INTISARI}

Dengan hadirnya Instruksi Presiden Nomor 3 Tahun 2003 tentang kebijakan dan Strategi Nasional Pengembangan e-government, maka presiden menginstruksikan agar melaksanakan pengembangan e-government secara nasional sesuai dengan tugas, fungsi dan kewenangan masing-masing. Langkah nyata dalam implementasi e-government di Kabupaten Probolinggo, khususnya Badan Kepegawaian Daerah adalah dibangunnya Sistem Informasi Administrasi Pegawai Online (SIAP Online). Penelitian ini bertujuan untuk menggambarkan Kerjasama Badan Kepegawaian Daerah dengan Organisasi Perangkat Daerah (OPD) lainnya dalam maupun Koordinasi antar bidang pada Badan Kepegawaian Daerah dalam pemanfaatan SIAP Online. Berdasarkan penelitian yang telah dilakukan diperoleh hasil bahwa kerjasama yang dilakukan Badan Kepegawaian Daerah dalam rangka penyajian data kepegawaian sudah berjalan baik. Ini dikarenakan adanya dukungan berupa peraturan daerah dan peraturan bupati yang memudahkan proses kerjasama dengan OPD lainnya. 


\section{Pendahuluan}

Era globalisasi ditandai dengan penggunaan teknologi informasi dan komunikasi (TIK), dimana salah satunya adalah internet. Diera transformasi menuju masyarakat informasi, internet tidak saja digunakan dalam dunia bisnis dan komersil melalui e-commerce tetapi juga digunakan dalam bidang pemerintahan, e-government.

Dasar hukum penyelenggaraan e-Government di Indonesia adalah Inpres Nomor 3 Tahun 2003 tentang Kebijakan dan Strategi Nasional Pengembangan e-Government. Melalui instruksi presiden tersebut, Presiden menginstruksikan kepada pejabat teras diseluruh jajaran instansi pemerintahan di Indonesia untuk mengambil langkah-langkah yang diperlukan sesuai dengan tugas, fungsi, dan kewenangan masingmasing guna melaksanakan pengembangan e-government secara nasional.

Karakteristik dari e-Government, yaitu suatu mekanisme interaksi baru (modern) antara pemerintah dengan masyarakat dan kalangan lain yang berkepentingan (stakeholder); dengan melibatkan penggunaan teknologi informasi (terutama internet); dengan tujuan memperbaiki mutu (kualitas) pelayanan yang sedang berjalan serta meningkatkan efisiensi manajemen pemerintahan, peningkatan kinerja dan tercapainya tata pemerintahan yang bersih, efektif, efisien, transparan, baik dalam pengelolaan internal maupun dalam pelayanan kepada publik (Indrajit, 2002, h. 4)

Langkah nyata dalam pengimplementasian e-Government di Kabupaten Probolinggo, khususnya pada Badan Kepegawaian Daerah (BKD) adalah dengan dibangunnya Sistem Informasi Administrasi Pegawai Online (SIAP Online). Kebijakan ini mengacu pada Undang Undang Nomor 43 Tahun 1999 tentang Perubahan atas Undang Undang Nomor 8 Tahun 1974 tentang Pokok-Pokok Kepegawaian, terutama terkait dengan perlunya penyelenggaraan dan pemeliharaan Informasi Kepegawaian; Keputusan Menteri Dalam Negeri Nomor 17 Tahun 2008 tentang Sistem Informasi Manajemen Kepegawaian Departemen Dalam Negeri dan Pemerintah Daerah; dan Peraturan Kepala Badan Kepegawaian Negara (BKN) Nomor 20 Tahun 2008 tentang Pedoman Pemanfaatan Sistem Aplikasi Pelayanan Kepegawaian.

Implementasi SIAP Online di Pemerintah Kabupaten Probolinggo, dimaksudkan untuk memberikan informasi dan menyediakan data Pegawai Negeri Sipil (PNS) agar tersusun lebih baik dalam rangka tertib administrasi yang selanjutnya dapat digunakan sebagai bahan analisis dalam menunjang pengambilan keputusan. Semua proses pengambilan keputusan memerlukan keterpaduan informasi yang akurat dan terpecaya. Hal tersebut terlaksana dengan adanya upaya dalam mengembangkan sistem informasi kepegawaian (Utomo, 2017).

Aplikasi SIAP Online bisa diakses pada alamat http://siap.bkd.probolinggokab.go.id/main/login.php; dimana dalam aplikasi tersebut berisikan semua informasi terkait data diri, karir, dan pengembangan PNS di Kabupaten Probolinggo. SIAP Online dibuat secara online dengan maksud mempermudah akses sistem yang tidak dibatasi oleh ruang dan waktu. Selain itu untuk mempermudah updating data dan sinkronisasi data yang dilakukan oleh admin pada tiap-tiap Oeganisasi Perangkat Daerah (OPD). Sistem informasi ini diharapkan dapat mempermudah proses administrasi kepegawaian, data pegawai dapat dilihat dimanapun dan kapanpun, lebih mudah dan cepat serta akurat sehingga bisa meningkatkan pelayanan BKD kepada pegawai, pimpinan, dan pihak terkait yang membutuhkan informasi tersebut secara langsung.

Setelah tiga tahun berjalan, aplikasi SIAP Online tidak berjalan seperti yang diharapkan. Hal ini salah satunya dikarenakan masih kurang aktif dalam melakukan peremajaan data. Leading sector dalam implementasi SIAP Online pada Badan Kepegawaian Daerah Kabupaten Probolinggo adalah Sub bidang Data dan Informasi Pegawai. Dalam Buku Pintar Kepegawaian Tahun 2015, berdasarkan Tugas Pokok Fungsi (Tupoksi) dari setiap bidang di BKD terdapat $73 \%$ berkas kepegawaian berasal dari internal BKD dan sisanya sebanyak 27\% berasal dari eksternal BKD (2015). Oleh karena itu dibutuhkan kerjasama yang lebih baik diinternal BKD maupun dieksternal BKD dalam penerapan SIAP online untuk percepatan akurasi data dan peremajaan data. Proses peremajaan data yang dilakukan dapat diperoleh melalui mekanisme kerjasama yang baik, sehingga data yang diperoleh seimbang sesuai tugas pokok dan fungsi (tupoksi).

Kerjasama menjadi hal yang mendapat perhatian khusus ketika temuan tentang ketidakseimbangan muncul dalam pengelolaan data terkait SIAP Online. Kerjasama menjadi kunci dalam penerapan SIAP Online, yakni dalam pengumpulan data dan berkas sebagai dasar untuk pengisian SIAP Online. Dalam pelaksanaan entry data sebanyak $73 \%$ dilakukan oleh BKD dan $27 \%$ oleh operator OPD yang diberi tugas melakukan entry data. Pembagian tugas tersebut sesuai dengan Peraturan Bupati Probolinggo Nomor 68 Tahun 2017 tentang Pedoman Pemanfaatan Sistem Informasi Administrasi Pegawai Online (SIAP Online) dan pemanfaatan Digital Filling System (DFS) pada lingkungan Pemerintah Kabupaten Probolinggo.

Namun pada kenyataannya, skenario diatas sesuai tugas dan fungsi tidak berjalan sesuai dengan yang diharapkan. Pegawai yang melakukan tugas entry data hanya sedikit jika melihat jumlah pegawai BKD secara keseluruhan dan kurang efisiennya penggunaan waktu 
dengan beban kerja yang harus dilaksanakan. Hal ini menyebabkan BKD tidak dapat melakukan entry data ke dalam SIAP Online tepat waktu meskipun data telah terkumpul. Dalam kasus tersebut terdapat beberapa hal yang juga menjadi perhatian, selain dari kerjasama, efektivitas, dan efisiensi kerja juga terkait motivasi sumber daya manusia dalam menjalankan tugas dilingkungan kerja. Seperti diketahui bahwa sumber daya manusia (SDM) merupakan aset yang paling penting dan membuat sumber daya lainnya bekerja. Simamora (1999) menyebutkan bahwa sumber daya manusia penting karena mempengaruhi efisiensi dan efektivitas organisasi, serta merupakan pengeluaran pokok organisasi dalam menjalankan kegiatan organisasinya.

Selain memahami kompetensi dan motivasi pegawai, perhatian mengenai kerjasama yang dilakukan oleh pemerintah daerah juga sangat erat kaitannya dengan kajian mengenai hubungan antar pemerintah (Intergovernmental Relations/ IGR). IGR menjadi sebagai kajian teori dalam menganalisis kondisi kerjasama di Badan Kepegawaian Daerah terkait penerapan SIAP Online karena didalamnya memuat penjelasan mengenai perspektif tindakan yang dilakukan berdasarkan kondisi yang diketahui sehingga hasil kajian dapat digunakan sebagai referensi untuk menyelesaikan masalah ketidakseimbangan kerjasama dalam pembagian tugas dalam pengumpulan data SIAP Online.

Berdasarkan beberapa hal tersebut diatas, penulis tertarik untuk melakukan penelitian untuk mengetahui dan mendeskripsikan koordinasi dan kerjasama serta faktor-faktor yang mempengaruhi penerapan SIAP Online pada Badan Kepegawaian Daerah Pemerintah Kabupaten Probolinggo.

\section{Teori}

\subsection{Intergovernmental Relations (IGR)}

Kerjasama antar pemerintah daerah (intergovernmental cooperation), didefinisikan sebagai "an arrangement between two or more governments for accomplishing common goals, providing a service or solving a mutual problem" (Patterson, 2008). Dalam definisi ini tersirat adanya kepentingan bersama yang mendorong dua atau lebih pemerintah daerah untuk memberikan pelayanan bersama atau memecahkan masalah secara bersama-sama.

\subsection{Konsep Kerjasama}

Kerjasama berasal dari bahasa Inggris, yaitu Cooperate, Cooperation, atau Cooperative. Dalam bahasa Indonesia disebut dengan istilah kerjasama atau bekerjasama. Adapun pengertian kerjasama adalah kegiatan atau usaha yang dilakukan oleh beberapa orang (lembaga, pemerintah) untuk mencapai tujuan bersama. Hafsah (2000) menyebut kerjasama dengan istilah "kemitraan", yang artinya adalah suatu strategi bisnis yang dilakukan oleh dua pihak atau lebih dalam jangka waktu tertentu untuk meraih keuntungan bersama dengan prinsip saling membutuhkan.

\subsection{IGR dalam Pemerintah Daerah}

Ada banyak pendekatan-pendekatan yang digunakan untuk menggambarkan IGR, misalnya pendekatan pusat dan daerah, pendekatan top down, dan pendekatan horizontal. Maksud dari pendekatan itu tidak lain untuk mendekatkan kepentingan-kepentingan pemerintah pusat ke pemerintah daerah. Secara konseptual/ teoritik pendekatan-pendekatan tersebut dijabarkan pada pendekatan desentralisasi, dekonsentrasi dan madebewind. Selain itu juga untuk mencapai efisiensi dan efektifitas pemerintah daerah, juga memberikan tanggung jawab kepada pemerintah daerah untuk mengatur, mengurus rumah tangganya sendiri melalui Undang-Undang Nomor 32 Tahun 2004 yang diganti menjadi Undang-Undang Nomor 23 Tahun 2014.

IGR memunculkan bermacam-macam istilah/ konsep/ nama. Secara konseptual IGR berawal dari konsep-konsep administrasi publik. Terdapat bermacammacam istilah yang memberikan arti terhadap IGR, antara lain desentralisasi, devolusi, dekonsentrasi, governance, dan leadership.

\subsection{Koordinasi dalam Administrasi Publik}

Menurut Handayaningrat (1982, h. 117), definisi koordinasi adalah "koordinasi dimaksudkan sebagai usaha menyatukan kegiatan-kegiatan dari satuan-satuan kerja (unit-unit) organisasi sehingga bergerak sebagai kesatuan seluruh tugas organisasi untuk mencapai suatu tujuan". Koordinasi yang baik dalam suatu organisasi atau instansi merupakan satu langkah agar pemikiran dari setiap sumber daya manusia yang ada pada instansi tersebut menjadi satu kesatuan sehingga tujuan yang diinginkan dapat tercapai. Dengan adanya koordinasi dalam hal pembagian kerja dari masing-masing sumber daya manusia, tugas yang dikerjakan akan terstruktur dan tersusun rapi, sehingga pekerjaan yang dilakukan merata dan tidak tumpang tindih antara satu dengan yang lainnya dapat dihindari.

\subsection{Administrasi Publik}

Rosenbloom dalam Pasolong (2007, h. 8), menunjukkan bahwa administrasi merupakan pemanfaatan teori-teori dan proses-proses manajemen, politik, dan hukum untuk memenuhi keinginan pemerintah di bidang eksekutif, legislatif, yudikatif dalam rangka fungsi-fungsi pengaturan, dan pelayanan terhadap masyarakat secara keseluruhan atau sebagian. Sedangkan pengertian publik adalah sejumlah manusia yang memiliki kebersamaan berpikir, perasaan, harapan, sikap, dan tindakan yang benar dan baik berdasarkan 
nilai-nilai norma yang mereka miliki (Syafiie, 2006). Chandler \& Plano dalam Keban (2004, h. 3), mengatakan bahwa administrasi publik adalah proses dimana sumber daya dan personil publik diorganisir dan dikoordinasikan untuk memformulasikan, mengimplementasikan, dan mengelola (manage) keputusan-keputusan dalam kebijakan publik. Administrasi publik juga berkaitan dengan organisasi dan manajemen seperti yang disampaikan oleh Wado dalam Darmadi \& Sukidin (2011) bahwa administrasi publik adalah organisasi dan manajemen dari manusia dan benda guna mencapai tujuan-tujuan pemerintah. Seperti yang diungkapkan oleh Luther Gulick mempopulerkan fungsi administrasi dan manajemen melalui bukunya berjudul Paper on the Science of Administration pada Tahun 1937. Konsep Gulick ini yang disingkat menjadi POSDCORB, memiliki kepanjangan Planning, Organizing, Staffing, Directing, Coordinating, Reporting, and Budgeting. (Gulick \& Urwick, 1937)

\subsection{Pemerintah Daerah}

Menurut Undang-Undang Nomor 23 Tahun 2014 tentang Pemerintahan Daerah Pasal 1 ayat (3) "Pemerintah daerah adalah kepala daerah sebagai unsur penyelenggara pemerintah daerah yang memimpin pelaksanaan urusan pemerintahan yang menjadi kewenangan daerah otonom Negara Kesatuan Republik Indonesia sebagaimana dimaksud dalam UndangUndang Dasar Negara Republik Indonesia Tahun 1945". Harris dalam Nurcholis (2007, h. 26), menjelaskan bahwa pemerintah daerah adalah pemerintahan yang diselenggarakan oleh badan-badan daerah yang dipilih secara bebas dengan tetap mengakui supremasi pemerintahan nasional. Pemerintahan ini diberi kekuasaan, diskresi (kebebasan mengambil kebijakan), dan tanggung jawab tanpa dikontrol oleh kekuasaan yang lebih tinggi. Dalam Undang-Undang Nomor 23 Tahun 2014, pemerintah daerah berwenang mengatur dan mengurus sendiri urusan pemerintahan menurut asas otonomi dan tugas pembantuan. Pemerintah daerah meliputi gubernur, bupati, walikota, dan perangkat daerah sebagai unsur penyelenggara pemerintahan daerah.

\subsection{Organisasi Perangkat Daerah}

Dwight Waldo dalam Sutarto (2002, h. 26) menyatakan bahwa organisasi adalah struktur hubungan diantara orang- orang berdasarkan wewenang dan bersifat tetap dalam suatu sistem administrasi. Perangkat daerah terdiri atas sekretariat daerah, dinas daerah, dan lembaga teknis daerah lainnya sesuai dengan kebutuhan daerah. Susunan organisasi perangkat daerah ditetapkan dengan peraturan daerah sesuai dengan pedoman yang ditetapkan pemerintah. Formasi dan persyaratan jabatan perangkat daerah ditetapkan dengan keputusan kepala daerah sesuai dengan pedoman yang ditetapkan pemerintah.

\section{Metode Penelitian}

Penelitian ini menggunakan jenis metode penelitian deskriptif eksplanatif dengan pendekatan kualitatif agar dapat melukiskan secara sistematis data dan fakta lalu melakukan analisis mengenai koordinasi internal dan eksternal terkait implementasi SIAP Online pada BKD Kabupaten Probolinggo serta faktor penghambat koordinasi tersebut, sehingga dapat diperoleh pemahaman yang mendalam tentang koordinasi antar bidang, subbidang, maupun intansi terkait dalam pengolahan data Pegawai Negeri Sipil dilingkungan Pemerintah Kabupaten Probolinggo

Penelitian ini memfokuskan kondisi Kerjasama BKD dengan OPD lainnya dan koordinasi antar bidang pada BKD dalam penerapan SIAP Online serta faktor pendukung dan penghambat kerjasama dan koordinasi tersebut.

Lokasi penelitian dilakukan BKD Kabupaten Probolinggo selaku leading sector dalam penerapan SIAP Online.

Adapun teknik pengumpulan data dilakukan melalui studi dokumentasi, observasi, wawancara terstruktur dan tidak terstruktur terhadap beberapa stakeholders yang terlibat dalam penerapan SIAP Online antara lain para pejabat di BKD dan Kasubbag Umum dan Kepegawaian OPD lainnya.

\section{Hasil Penelitian dan Pembahasan}

\subsection{Kondisi Kerjasama BKD dengan OPD Lainnya}

Dalam melaksanakan kebijakan pengelolaan data kepegawaian BKD telah melakukan kerjasama dengan OPD lainnya. Kerjasama dibangun dalam rangka bagaimana data yang dihasilkan dapat diimplementasikan dalam proses pengembangan sumber daya manusia aparatur yang ada di Kabupaten Probolinggo. Kolaborasi yang baik antar OPD yang ada di Kabupaten Probolinggo dalam penatausahaan data kepegawaian merupakan sebuah modal dalam mewujudkan data yang transparan dan akuntabel.

Kolaborasi yang telah dilaksanakan melalui pertemuan-pertemuan yang bersifat konsolidasi. Membangun komitmen dalam penanganan urusan kepegawaian dalam konteks kerjasama Badan Kepegawaian Daerah dengan OPD juga telah dilaksanakan dalam rangka meningkatkan motivasi dan kinerja pegawai. Pemberian penghargaan atas kinerja dan sanksi atas tindakan yang dilakukan pegawai yang ada di Kabupaten Probolinggo, didasarkan atas usulan dan masukan dari Kepala OPD. Artinya bahwa koordinasi telah berjalan dengan baik, sehingga segala tindakan yang berkaitan dengan urusan kepegawaian telah melalui 
proses sesuai dengan peraturan perundang - undangan yang berlaku dan tidak memihak, tetapi berdasarkan fakta yang ada.

\subsection{Kondisi Kerjasama BKD dengan OPD Lainnya dalam Pemutakhiran Data SIAP Online}

Dalam penatausahaan data kepegawaian di Kabupaten Probolinggo yang lebih akuntabel, telah diimplementasikan kebijakan penggunaan aplikasi SIAP Online. Untuk mendukung operasional aplikasi SIAP Online, Badan Kepegawaian Daerah telah membuat Standar Operasional Prosedur (SOP) agar dapat memudahkan dalam pelaksanaannya. Dalam updating data pada SIAP Online, perubahan data berdasarkan entry dari operator OPD, yang selanjutnya akan diverifikasi dan divalidasi oleh pengelola data kepegawaian di BKD berdasarkan berkas pendukung yang dilampirkan oleh OPD.

Kerjasama yang baik antara BKD dan OPD lainnya dapat dilihat dari jumlah perubahan data pegawai yang dientrykan oleh operator OPD. $73 \%$ data yang berada pada SIAP Online merupakan produk yang dikeluarkan oleh BKD, sedangkan $27 \%$ sisanya merupakan tugas dari OPD. Dapat diartikan peran dalam pemutakhiran data lebih banyak dilakukan oleh bidang - bidang internal Badan Kepegawaian Daerah. Tetapi dari hasil penelitian yang dilakukan OPD dengan aktif juga melakukan perubahan data yang seharusnya menjadi tanggung jawab internal BKD. Dalam rentang waktu satu tahun dimulai dari Bulan Juli 2018 - Juni 2019 tercatat sebanyak 12.228 permintaan perubahan data pegawai. Percepatan peremajaan data pegawai oleh OPD dilakukan agar data kepegawaian pada SIAP Online bisa akurat dan akuntabel, sehingga dalam memberikan layanan kepegawaian bisa berjalan dengan sesuai harapan. Hal ini merupakan tujuan bersama antara BKD dan OPD, khususnya Sub Bagian Umum dan Kepegawaian tiap tiap OPD.

Kondisi yang baik ini dikarenakan sudah adanya pemahaman bahwa tugas penatausahaan kepegawaian tidak hanya menjadi tanggung jawab Badan Kepegawaian Daerah, tetapi melekat dimasing-masing OPD, dengan BKD sebagai koordinator didalamnya. Rapat koordinasi sudah dilaksanakan secara rutin, tidak hanya ditingkat pimpinan, tetapi rapat koordinasi dilaksanakan ditingkat Kepala Sub Bagian Umum dan Kepegawaian dan operator SIAP Online. Kerjasama antar pengelola data kepegawaian sudah berjalan dengan baik, dengan diadakannya rapat koordinasi dan pertemuanpertemuan dalam rangka rekonsiliasi data kepegawaian.

BKD juga memberikan waktu dan tempat kepada para operator manakala ada masalah terkait dengan aplikasi SIAP Online. Kondisi lingkungan kerja yang kondusif ini berdampak pada hasil kerja dari para aparatur yang bertugas dalam penatausahaan data kepegawaian melalui SIAP Online.

Kerjasama antara BKD dengan OPD lainnya diperkuat dengan diterbitkannya Peraturan Bupati Nomor 68 Tahun 2017 tentang Pedoman Pemanfaatan Sistem Informasi Administrasi Pegawai Online (SIAP Online) dan Pemanfaatan Digital Filling System (DFS) di Lingkungan Pemerintah Kabupaten Probolinggo. Kerjasama yang sudah terjalin bisa lebih efektif dengan menyederhanakan SOP pemutakhiran data SIAP Online. Penyederhanaan SOP dengan memberikan akses kepada masing-masing PNS untuk meng-entry-kan langsung ke aplikasi, tetapi penyederhanaan SOP ini diikuti dengan pengembangan aplikasi dengan menambahkan fungsi unggah berkas pendukung perubahan data, sehingga memudahkan BKD untuk memverifikasi perubahan tersebut.

\subsection{Bentuk Koordinasi Antar Bidang Dalam Pemutakhiran Data SIAP Online}

Berdasarkan tugas pokok dan fungsi masing-masing bidang di Badan Kepegawaian Daerah, $73 \%$ data Kepegawaian berasal dari internal BKD, oleh karenanya dibutuhkan koordinasi agar data kepegawaian yang berada pada Aplikasi SIAP Online bisa akurat dan up to date. Dengan Struktur Organisasi BKD sesuai dengan Peraturan Bupati Probolinggo Nomor 83 Tahun 2016 tentang Kedudukan, Susunan Organisasi, Uraian Tugas dan Fungsi Serta Tata Kerja Badan Kepegawaian Daerah Kabupaten Probolinggo; Penerapan SIAP Online dilaksanakan oleh Sub Bidang Data dan Informasi.

Namun dalam hal pembaharuan data, Sub Bidang Data dan Informasi tidak bisa sendiri dan membutuhkan dukungan data dari semua sub bidang yang ada pada Badan Kepegawaian Daerah. Masing-masing Sub Bidang meng-entry-kan data sesuai dengan tugas pokok dan fungsi (Tupoksi) kedalam SIAP Online. Mekanisme peremajaan data oleh semua Sub Bidang sudah diatur dalam SOP yang tertuang dalam lampiran Peraturan Bupati Nomor 68 Tahun 2017; dimana semua sub bidang melakukan entry data disertai bukti dukung berupa berkas fisik sebagai dasar validasi data yang dilakukan oleh Sub Bidang Data dan Informasi.

Koordinasi antar bidang pada BKD sudah berjalan dengan baik, tetapi masih perlu adanya penguatan. Rapat staf yang dilaksanakan secara rutin setiap bulan dan dipimpin oleh Sekretaris BKD sebagai seorang koordinator. Rapat staf tersebut, sebagai media untuk evaluasi dan memberikan gambaran pelaksanaan program dan kegiatan yang dilaksanakan masing-masing bidang. Selain itu juga diberikan kesempatan untuk menyampaikan progres atas kegiatan yang dilaksanakan, termasuk disampaikan hambatan yang dihadapi dan masukan akan solusi pemecahan masalah untuk meminimalisir hambatan tersebut. Selanjutnya Kepala 
BKD memberikan instruksi kepada masing-masing bidang, sehingga antara pimpinan dan pelaksana kegiatan menjadi serasi, seirama dan terpadu dalam pencapaian tujuan.

\subsection{Mekanisme Koordinasi Antar Bidang Dalam Pemutakhiran Data SIAP Online}

Masing-masing Sub Bidang meng-entry-kan data sesuai dengan tugas pokok dan fungsi ke dalam SIAP Online, sehingga data bisa diproses oleh sistem dan menghasilkan informasi yang akurat. Oleh karena itu diperlukan koordinasi antar bidang agar memudahkan penatausahaan data kepegawaian dalam pemanfaatan SIAP Online.

Badan Kepegawaian Daerah sudah menggunakan SOP dalam pemutakhiran data SIAP Online. SOP dibutuhkan sebagai panduan dalam pelaksanaan pemutakhiran data SIAP Online, agar dalam penatausahaan kepegawaian tidak terjadi hambatan yang dapat menyebabkan Badan Kepegawaian Daerah tidak dapat menyediakan data kepegawaian yang akurat dan akuntabel. Prosedur kerja/ SOP pemutakhiran data SIAP Online yang tertuang dalam lampiran Peraturan Bupati Probolinggo Nomor 68 Tahun 2017 mengatur tentang mekanisme pembaharuan data oleh semua sub bidang, dimana semua sub bidang melakukan entry data disertai bukti bukti dukung berupa berkas fisik sebagai dasar validasi data yang dilakukan oleh Sub Bidang Data dan Informasi. Berkas kepegawaian dan laporan data mutasi kepegawaian dikirim ke Bidang Pengadaan, Penghentian, Data, dan Informasi untuk dihimpun dan selanjutnya diteruskan ke Sub Bidang Data dan Informasi Pegawai untuk dilakukan verifikasi/ validasi pemutakhiran database. Berkas kepegawaian yang sudah dimutakhirkan kemudian didokumentasikan untuk selanjutnya disusun sebagai dokumen Tata Naskah Kepegawaian berdasarkan urut Nomor Identitas Pegawai (NIP).

Penyerahan berkas mutasi data pegawai dari masing-masing sub bidang yang ada pada Badan Kepegawaian Daerah kepada Bidang Pengadaan, Penghentian, Data, dan Informasi disertai dengan berita acara serah terima berkas perubahan data pegawai. Berita acara ini sebagai bukti bahwa sub bidang yang bersangkutan sudah selesai melakukan entry data pegawai, yang selanjutnya akan divalidasi oleh Sub Bidang Data dan Informasi Pegawai.

SOP yang ada perlu dilakukan penyederhanaan, dimana proses entry data dilakukan oleh Sub Bidang Data dan Informasi, sedangkan bidang-bidang yang ada pada Badan Kepegawaian Daerah hanya memberikan rekapitulasi perubahan data pegawai disertai berkas pendukungnya dan melakukan pengecekan apakah perubahan data pegawai sudah di-entry atau belum.

\subsection{Faktor Pendukung dalam Pemutakhiran Data SIAP Online}

\subsubsection{Adanya Peraturan Daerah dan Peraturan Bupati terkait Susunan Organisasi dan Tata Kerja OPD di Kabupaten Probolinggo}

Dalam implementasi kebijakan penggunaan aplikasi SIAP Online dalam pengelolaan data kepegawaian yang ada di Kabupaten Probolinggo, tidak hanya pada BKD saja yang melakanakan urusan kepegawaian, namun setiap OPD juga mempunyai fungsi untuk melaksanakan urusan kepegawaian melalui tugas dan fungsi Kepala Sub Bagian Umum dan Kepegawaian. Dengan dukungan tugas dan fungsi Kepala Sub Bagian Umum dan Kepegawaian ini, akan memudahkan sinergi antara BKD dengan OPD lainnya dalam rangka pengelolaan data kepegawaian menggunakan SIAP Online.

\subsubsection{Adanya Pembagian Tugas dan Fungsi bidang dalam penerapan SIAP Online}

Berdasarkan Peraturan Bupati Probolinggo, Sub Bidang Data dan Informasi merupakan unit yang menangani/ leading sector dalam hal pemutakhiran data yang dibantu oleh sub bidang lainnya. Untuk memudahkan koordinasi, BKD memiliki SOP pemutakhiran data, dimana semua bidang meng-entrykan data kedalam SIAP online sesuai dengan tupoksinya dan menyerahkan berkas fisik kepada Sub Bidang Data dan Informasi yang kemudian dilakukan validasi data oleh sub bidang tersebut.

\subsubsection{Adanya Peraturan Bupati Nomor 95 Tahun 2016 tentang Tambahan Penghasilan Bagi PNS di Lingkungan Pemkab. Probolinggo}

Penguatan motivasi dan semangat kerja dalam pelaksanaan tugas sehari-hari, termasuk pelaksanaan aplikasi Siap Online diperlukan dalam rangka konsistensi dan keberlanjutan dari kebijakan yang telah dilaksanakan. Pemberian tambahan penghasilan bagi PNS bertujuan merangsang kinerja agar lebih termotivasi dan semangat dalam menjalankan tugas-tugas. Dengan tambahan penghasilan, PNS dituntut untuk lebih disiplin melaksanakan kewajibannya. Untuk mendapatkan tambahan penghasilan dengan nominal yang maksimal menurut standar yang telah ditetapkan, para pengelola kepegawaian, harus melaksanakan rekonsiliasi dan update data kepegawaian secara rutin dan tepat waktu.

\subsubsection{Pemberian Honorarium bagi Operator}

Untuk menunjang pelaksanaan aplikasi SIAP Online dalam pengelolaan data kepegawaian, sehingga dapat berjalan sesuai yang diharapkan, Pemerintah Kabupaten Probolinggo memberikan honor setiap bulan sesuai 
dengan amanah peraturan Bupati Probolinggo Nomor 39 Tahun 2018 tentang Standar Biaya Umum Anggaran Pendapatan dan Belanja Daerah. Pemberian honor ini dimaksudkan agar para operator SIAP Online dapat bekerja dengan semangat dan mempunyai komitmen yang tinggi, berkinerja dengan baik, sehingga penerapan aplikasi ini berjalan dengan baik di masing - masing OPD.

\subsubsection{Rapat Internal yang Dilaksanakan Secara Rutin}

Sehubungan dengan amanah yang terkandung dalam Peraturan Bupati Probolinggo Nomor 83 Tahun 2016, maka mengharuskan dilaksanakan koordinasi dalam internal Badan Kepegawaian Daerah. Salah satu koordinasi internal yang dilakukan adalah koordinasi dalam rangka pemutakhiran data pada SIAP Online berupa rapat internal yang dilaksanakan secara rutin dan berkala yang diikuti oleh para staf, eselon IV, dan eselon III.

Dalam rapat internal yang diadakan rutin setiap bulan sekali ini, diadakan diskusi sebagai media sharing atas permasalahan yang ada dan mencari solusi pemecahannya. Pada kesempatan ini juga diadakan evaluasi tentang pemutahkiran data pegawai. Rapat internal ini dipimpin oleh Kepala Badan dan dihadiri juga oleh sekretaris badan selaku koordinator dalam implementasi SIAP Online, sehingga memudahkan dalam koordinasi antar bidang diinternal Badan Kepegawaian Daerah.

\subsubsection{Aplikasi yang Mudah Dipahami dalam Operasionalnya}

Aplikasi SIAP Online ini merupakan aplikasi berbasis web yang dapat dikerjakan dimana saja secara online. Dengan aplikasi SIAP Online, BKD dapat menyajikan data kepegawaian yang lebih baik dan berkualitas, termasuk data kepegawaian yang ada diseluruh OPD secara cepat dan akurat. Saat ini hampir semua operator SIAP Online tidak ada kesulitan untuk memahami dan mengoperasionalkan aplikasi tersebut. Namun demikian butuh komitmen dan konsistensi untuk updating datanya agar data yang ada sesuai dengan kondisi yang sebenarnya.

\subsubsection{Pendampingan oleh BKD kepada Operator}

Para operator SIAP Online direkrut tiap OPD, yang selanjutnya diberikan bimbingan teknis sebelum melaksanakan penatausahaan data kepegawaian. Pemahaman akan aplikasi SIAP Online didapat para operator melalui materi yang diberikan selama pelaksanaan bimbingan teknis. Pendampingan ini bersifat terus menerus, tidak hanya sebatas waktu pelaksanaan bimbingan teknis saja, namun setelah pelaksanaan bimbingan teknis BKD tetap memberikan pendampingan kepada para operator. Operator bisa langsung datang ke kantor BKD, atau bisa melakukan diskusi dan koordinasi melalui media sosial, baik itu whatsapp group maupun facebook yang sudah disiapkan oleh administrator dan pengolah data SIAP Online.

\subsubsection{Komitmen Staf Dalam Melaksanakan Kegiatan}

Komitmen sangat dibutuhkan dalam keberhasilan sebuah program kegiatan, tiap sub bidang saling membantu dan bekerjasama dalam penerapan SIAP Online demi kepentingan bersama. Data yang di-entrykan diolah menjadi sebuah informasi yang terintegrasi, sehingga bisa dimanfaaatkan kembali oleh masingmasing sub bidang maupun pengambilan kebijakan oleh pimpinan. Dengan komitmen yang tinggi dan koordinasi yang baik, dapat menumbuhakan kesadaran diantara para pejabat dan staf, sehingga menghindarkan kemungkinan timbulnya pertentangan antar pejabat serta menghindarkan perasaan atau suatu pendapat bahwa sub bidang atau bidangnya merupakan yang paling penting.

\subsubsection{Kebijakan Pimpinan yang Mendukung Percepatan Keakuratan Data Pegawai}

Kebijakan pimpinan dengan melampirkan ringkasan data profil PNS dalam setiap pelayanan kepegawaian terbukti mempercepat pemutakhiran data pegawai pada SIAP online. Ringkasan data profil PNS dapat dicetak melalui website BKD oleh PNS yang bersangkutan, dimana data yang ditampilkan di website terintegrasi dengan database SIAP Online. Hal ini mewajibkan agar seluruh PNS yang mengajukan layanan kepegawaian harus memastikan bahwa data yang ada apa SIAP Online sudah benar. Agar kebijakan ini berjalan dengan baik, diperlukan komitmen oleh seluruh bidang di BKD untuk mengecek keaslian dan kebenaran data yang ada pada cetak profil pegawai melalui QR Code.

\subsection{Faktor Penghambat dalam Pemutakhiran Data SIAP Online}

\subsubsection{Beban Tugas Sub Bagian Umum OPD}

Dalam melakukan peremajaan data, operator OPD masih sering terlambat, hal ini dikarenakan terbatasnya staf pada sub bagian umum dan kepegawaian tiap OPD. Dengan terbatasnya staf dan banyaknya tugas pokok dan fungsi sub bagian umum kepegawaian serta banyaknya aplikasi lainnya, mengharuskan kepala sub bagian untuk mengoptimalkan para staf agar bisa menjalankan semua tugas dengan cara memberikan skala prioritas mana yang akan diselesaikan terlebih dahulu.

\subsubsection{Mutasi Pegawai}

Dalam Peraturan Bupati Probolinggo Nomor 68 Tahun 2017; diamanatkan agar setiap kepala OPD mengangkat operator untuk aplikasi SIAP Online. Diharapkan keberadaan operator pada masing-masing 
OPD dapat dipertahankan sesuai kebutuhan. Hal ini dikarenakan pengangkatan operator di OPD sudah dibekali dengan pengetahuan dan kemampuan dalam mengoperasionalkan aplikasi SIAP Online.

Namun demikian pola mutasi staf yang dilakukan tidak seiring dengan kebutuhan operator yang ada pada masing-masing OPD. Ada beberapa operator SIAP Online yang dimutasi ke OPD lainnya. Hal ini jelas akan menjadi kendala dalam mengimplementasikan aplikasi SIAP Online. Operator yang lama tidak melakukan transformasi pengetahuan kepada penggantinya sehingga harus dimulai lagi dari awal dalam membentuk sesorang staf menjadi operator dan ini memerlukan waktu bagi operator baru dalam mengimplementasikan aplikasi SIAP Online.

\subsubsection{Sarana dan Prasarana Kurang Memadai}

Aplikasi SIAP Online merupakan aplikasi online dengan berbasis pada jaringan internet yang ada pada masing-masing OPD. Faktor jaringan yang baik sangat berpengaruh pada proses input dan validasi yang ada pada BKD. Dari hasil penelitian, masih ada masalah terkait dengan jaringan internet, terutama pada kecamatan yang terletak pada dataran tinggi dan pegunungan.

Selain masalah jaringan, hambatan juga terjadi pada ketersediaan komputer yang dipakai. Nilai ekonomis server dan komputer dengan nilai ekonomis barang sudah lebih lima tahun juga menjadi kendala yang harus segera diatasi. Dengan kondisi kinerja server dan komputer yang lambat dan tidak maksimal, akan mengganggu operator dalam menjalankan fungsinya. Hal yang perlu diperhatikan terkait dengan kemampuan kinerja server dan komputer yang sudah menurun adalah melakukan perencanaan pengadaan dengan spesifikasi sesuai dengan yang dibutuhkan.

\subsubsection{Kurang Memahami SOP yang Disusun}

Data yang disajikan pada SIAP Online digunakan oleh BKD dalam memberikan layanan kepegawaian yang lebih baik kepada semua pegawai pada lingkungan Pemkab. Probolinggo maupun kepada para pimpinan dalam mengambil keputusan. Selain itu SIAP Online juga dimanfaatkan oleh OPD lainnya dalam rangka penyelenggaraan Sistem Pemerintahan Berbasis Elektronik terintegrasi.

Berdasarkan evaluasi yang dilakukan, terkadang proses entry data tidak berjalan baik. Adanya keterlambatan dalam proses entry data yang disebabkan karena adanya keterlambatan data dari bidang lain atau operator yang tidak segera melakukan entry data. Hal ini menunjukkan bahwa SOP yang telah disusun dalam melakukan penatausahaan data kepegawaian dengan apikasi SIAP Online tidak dijadikan pedoman dalam prosesnya.

\subsubsection{Jumlah Pegawai yang Kurang}

Proses entry data yang tidak sesuai dengan SOP juga dipengaruhi oleh beban kerja seorang operator SIAP online. Karena sesungguhnya masing-masing operator memiliki tugas pokok dan fungsi sesuai dengan jabatan dan sub bidangnya. Sehingga proses entry data dilakukan setelah tugas pokoknya selesai. Perilaku seperti ini bisa dikatakan wajar, karena berkaitan dengan perjanjian kinerja dan Sasaran Kinerja Pegawai (SKP), sehingga lebih memprioritaskan tugas pokoknya. Sangat wajar jika pegawai yang ada di BKD kelebihan beban kerja, ini bisa dilihat dari jumlah pegawai dilingkungan Pemkab. Probolinggo sebanyak 7.630 orang dibanding jumlah pegawai yang ada di BKD sebanyak 53 orang, dimana staf yang melakukan seluruh pelayanan kepegawaian hanya 21 orang.

\section{Kesimpulan}

Berdasarkan hasil penelitian dan pembahasan tentang Kerjasama Badan Kepegawaian Daerah dengan Organisasi Perangkat Daerah lainnya pada lingkungan Pemerintah Kabupaten Probolinggo dalam penerapan Sistem Informasi Administrasi Pegawai (SIAP Online) dapat ditarik kesimpulan sebagai berikut:

a) Kondisi Kerjasama BKD dengan OPD lainnya sudah berjalan dengan cara melakukan sinergi yang baik dalam penatausahaan data kepegawaian. Telah dilaksanakannya pertemuan - pertemuan yang bersifat konsolidasi antara lain koordinasi dengan kepala OPD dalam rangka menjalankan fungsi pembinaan dan meningkatkan motivasi aparatur dalam kerja

b) Dalam penatausahaan data kepegawaian di Kabupaten Probolinggo yang lebih cepat, akurat, dan akuntabel, telah diimplementasikan kebijakan penggunaan aplikasi SIAP Online. Penggunaan aplikasi ini telah membantu Pemerintah Kabupaten Probolinggo lebih cepat, akurat dan akuntabel dalam penyediaan data kepegawaian

c) Penguatan koordinasi antar bidang pada Badan Kepegawaian Daerah dilakukan melalui instruksi pimpinan dalam rapat staf rutin yang diadakan setiap bulan yang diikuti oleh semua bidang

d) Badan Kepegawaian Daerah sudah menggunakan SOP dalam pemutakhiran data SIAP Online yang tertuang dalam lampiran Peraturan Bupati Probolinggo Nomor 68 Tahun 2017. Perbub tersebut mengatur tentang mekanisme pembaharuan data oleh semua sub bidang

e) Faktor pendukung kerjasama dan koordinasi dalam pemutakiran data SIAP Online sebagai berikut:

- Adanya Peraturan Daerah dan Peraturan Bupati terkait Susunan Organisasi dan Tata Kerja Organisasi Perangkat Daerah di Kabupaten Probolinggo; 
- Adanya pembagian tugas dan fungsi bidang dalam penerapan SIAP Online;

- Adanya Peraturan Bupati Probolinggo Nomor 95 Tahun 2016 tentang Tambahan Penghasilan Bagi Pegawai Negeri Sipil pada lingkungan Pemerintah Kabupaten Probolinggo;

- Pemberian honorarium bagi para operator;

- Rapat koordinasi yang dilaksanakan secara rutin;

- Aplikasi yang mudah dipahami dalam operasionalnya;

- Pendampingan oleh Badan Kepegawaian Daerah terhadap operator;

- Komitmen staf dalam melaksanakan kegiatan; dan

- Adanya kebijakan pimpinan yang mendukung percepatan keakuratan data pegawai.

f) Faktor pendukung kerjasama dan koordinasi dalam pemutakiran data SIAP Online sebagai berikut:

- Beban tugas Sub Bagian Umum OPD yang terlalu berat;

- Mutasi pegawai yang menjadi operator aplikasi;

- Sarana dan prasarana yang kurang memadai; dan

- Kurang memahami SOP yang disusun.

Berdasarkan kesimpulan diatas, maka saran dan rekomendasi yang ingin penulis berikan adalah sebagai berikut:

a) Perlunya rekonsiliasi atau pencocokan data yang lebih sering dilaksanakan, minimal setiap tiga bulan sekali. Ini merupakan salah satu usaha dalam rangka penguatan kerjasama antara Badan Kepegawaian Daerah dengan OPD lainnya agar data kepegawaian tetap akurat dan akuntabel;

b) Menyederhanakan SOP pemutakhiran data $27 \%$ berkas kepegawaian yang berasal dari PNS yang bersangkutan. Dimana dalam SOP yang baru, Badan Kepegawaian memberikan akses kepada masing masing PNS untuk mengentrykan langsung data kepegawaiannya ke dalam Aplikasi SIAP Online;

c) Perlu dibuatnya forum koordinasi dan konsultasi teknis dilingkungan internal Badan Kepegawaian Daerah dengan menggunakan platform media sosial, sehingga koordinasi bisa secara cepat dilakukan;

d) Menyederhanakan SOP peremajaan data kepegawaian, dimana dalam SOP yang baru proses entry data dilakukan oleh sub bidang data dan informasi, sedangkan bidang-bidang yang ada pada Badan Kepegawaian Daerah hanya memberikan rekapitulasi perubahan data pegawai disertai berkas pendukungnya; dan

e) Untuk mengurangi hambatan dalam pemutakhiran data SIAP Online, maka OPD harus menyiapkan operator cadangan, sehingga jika terjadi mutasi maka pelaksanaan peremajaan data pegawai tidak terganggu. Sedangkan kendala di sektor sarana dan prasarana, Badan Kepegawaian Daerah harus bekerjasama dengan Dinas Komunikasi, Informatika,
Statistik dan Persandian dalam hal penyediaan teknologi, terutama dalam hal koneksi internet. Selain itu berkonsultasi dengan Diskominfo untuk mendapatkan rekomendasi spesifikasi barang, khususnya komputer dan server agar tepat guna dan optimal dalam penggunaannya.

\section{Daftar Pustaka}

Darmadi, Damai., \& Sukidin. (2011). Administrasi Publik. Yogyakarta: Laksbang PRESSindo.

Gulick, Luther., \& Lyndall Urwick. (1937). Papers on the science of administration. New York: Instituteof Public Administration, Columbia University.

Hafsah, Muhammad Jafar. (2000). Kemitraan Usaha: Konsepsi dan Strategi. Pustaka Sinar Harapan, Jakarta.

Handayaningrat, Soewarno. (1982). Pengantar ilmu administrasi dan Manajemen. Jakarta: PT. Toko Gunung Agung.

Indrajit, Richardus Eko. (2002). E-Government : Strategi Pembangunan Dan Pengembangan Sistem Pelayanan Publik Berbasis Teknologi Digital. Yogyakarta: Andi Offset.

Keban, T. Yeremias. (2004). Enam Dimensi Strategis Administrasi Publik, Konsep, Teori, dan Isu. Gava Media, Yogyakarta.

Nurcholis, H. (2007). Teori dan Praktik: Pemerintahan dan Otonomi Daerah. Jakarta: Grasindo.

Pasolong, Harbani. (2007). Teori Administrasi Publik. Bandung: Alfabeta.

Patterson, D. (2008). Intergovernmental Cooperation. Albany: New York State Department of State Division of Local Government Service.

Simamora, Henry. (1999). Manajemen Sumber Daya Manusia, Edisi ke-2, Cetakan Kedua. Yogyakarta: Bagian Penerbitan STIE YKPN.

Sutarto. (2002). Dasar-Dasar Organisasi. Yogyakarta: Gadjah Mada University Press.

Syafiie, Inu Kencana. (2006). Ilmu Administrasi Publik. Jakarta: Rineka Cipta.

Utomo, Pangurifan. (2017). Sistem Informasi Administrasi Kepegawaian Berbasis Web pada PT. Argo Pantes Tanggerang. Skripsi, STMIK Nusa Mandiri, Jakarta. 